\title{
Effects of microcystin-LR in isolated perfused rat kidney
}

A.C.L. Nobre ${ }^{1}$

M.C.M. Jorge ${ }^{1}$,

D.B. Menezes²,

M.C. Fonteles ${ }^{1}$ and

H.S.A. Monteiro ${ }^{1}$

\author{
1Departamento de Fisiologia e Farmacologia and \\ 2Patologia e M edicina Legal, Faculdade de Medicina, \\ Universidade Federal do Ceará, Fortaleza, CE, Brasil
}

\section{Correspondence \\ H.S.A. Monteiro \\ Departamento de Fisiologia e \\ Farmacologia, FM, UFC \\ Rua Cel. Nunes de Melo, 1127 \\ 60430-270 Fortaleza, CE \\ Brasil \\ Fax: + 55-85-243-9333 \\ E-mail: serrazul@ truenet-ce.com.br \\ Research supported by CAPES and CNPq.}

Received April 14, 1998

Accepted March 29, 1999

\section{Abstract}

Microcystin is a hepatotoxic peptide which inhibits protein phosphatase types 1 and $2 \mathrm{~A}$. The objective of the present study was to evaluate the physiopathologic effects of microcystin-LR in isolated perfused rat kidney. Adult Wistar rats $(\mathrm{N}=5)$ of both sexes $(240-280$ g) were utilized. Microcystin-LR $(1 \mu \mathrm{g} / \mathrm{ml})$ was perfused over a period of $120 \mathrm{~min}$, during which samples of urine and perfusate were collected at 10-min intervals to determine the levels of inulin, sodium, potassium and osmolality. We observed a significant increase in urinary flow with a peak effect at $90 \mathrm{~min}(\operatorname{control}(\mathrm{C})=0.20 \pm 0.01$ and treated $\left.(\mathrm{T})=0.32 \pm 0.01 \mathrm{ml} \mathrm{g}^{-1} \mathrm{~min}^{-1}, \mathrm{P}<0.05\right)$. At 90 min there was a significant increase in perfusate pressure $(\mathrm{C}=129.7 \pm 4.81$ and $\mathrm{T}=$ $175.0 \pm 1.15 \mathrm{mmHg})$ and glomerular filtration rate $(\mathrm{C}=0.66 \pm 0.07$ and $\left.\mathrm{T}=1.10 \pm 0.04 \mathrm{ml} \mathrm{g}^{-1} \mathrm{~min}^{-1}\right)$ and there was a significant reduction in fractional sodium tubular transport at $120 \mathrm{~min}(\mathrm{C}=78.6 \pm 0.98$ and $\mathrm{T}=73.9 \pm 0.95 \%)$. Histopathologic analysis of the perfused kidneys showed protein material in the urinary space, suggestive of renal toxicity. These data demonstrate renal vascular, glomerular and urinary effects of microcystin-LR, indicating that microcystin acts directly on the kidney by probable inhibition of protein phosphatases.
Key words

- Microcystin-LR

- Kidney

- Perfused kidney
Members of the cyanobacterial genera Microcystis, Oscillatoria and Anabaena produce cyclic peptides, denoted microcystins, which are potent hepatotoxins. These substances are responsible for the death of fish, birds, wild animals and agricultural livestock in many countries where freshwaters contain toxic cyanobacterial blooms, and the adverse effects of these toxins on human health have been recognized $(1,2)$.

Microcystin-LR (MCLR) is a highly hepatotoxic heptapeptide in mice and rats, which consists of two variable L-amino acids, i.e., leucine and arginine, three D-amino acids and the two unusual amino acids, N-methyldehydroalanine and 3-amino-9-methoxy-10phenyl-2,6,8-trimethyl-deca-4(E),6(E)dienoic acid (Adda) $(3,4)$. MCLR has been shown to inhibit significantly the catalytic subunits of only two specific types of protein phosphatases, protein phosphatase 1 (pp-1c) and protein phosphatase $2 \mathrm{~A}$ (pp-2Ac) (5-8). The purpose of the present study was to evaluate and compare the physiopathologic effects of microcystin-LR (Sigma Chemical Co., Saint Louis, MO, USA; molecular mass 
995.2) from Microcystis aeruginosa on the isolated perfused kidney without blood cells.

Adult Wistar rats of both sexes weighing 240-280 g were anesthetized with sodium pentobarbital $(50 \mathrm{mg} / \mathrm{kg}$ body weight $i p)$. Twenty percent mannitol was administered intravenously just before the right ureter was cannulated with polyethylene (PE50) tubing. The right renal artery was cannulated with a 19-gauge blunt disposable needle passed through the superior mesenteric artery as described by Bahlmann et al. (9), Nishiitsutji-Uwo et al. (10) and Ross (11). The excised right kidney was perfused without interruption of kidney flow at $37^{\circ} \mathrm{C}$ with Krebs-Henseleit buffer containing $6 \mathrm{~g} / \mathrm{l}$ bovine serum albumin (BSA fraction V, Sigma). The perfusion solution was dialyzed for $48 \mathrm{~h}$ at $4^{\circ} \mathrm{C}$ in 1.51 of Krebs to reduce its contamination, and its $\mathrm{pH}$ was adjusted to 7.4. The total perfusate used per experiment was 100 $\mathrm{ml}$ and contained: $147 \mathrm{mmol} / 1 \mathrm{Na}^{+}, 5 \mathrm{mmol} / \mathrm{l}$ $\mathrm{K}^{+}, 2.5 \mathrm{mmol} / \mathrm{l} \mathrm{Ca}^{2+}, 2 \mathrm{mmol} / \mathrm{l} \mathrm{Mg}^{2+}, 110$ $\mathrm{mmol} / \mathrm{l} \mathrm{Cl}^{-}, 2.5 \mathrm{mmol} / 1 \mathrm{HCO}_{3}{ }^{-}, 1 \mathrm{mmol} / 1$ $\mathrm{SO}_{4}{ }^{2-}, 1 \mathrm{mmol} / 1 \mathrm{PO}_{4}{ }^{3-}, 0.075 \mathrm{~g}$ urea, $0.075 \mathrm{~g}$ inulin and $0.15 \mathrm{~g}$ glucose. The perfusion system was based on Bowman's technique (12) as modified in our laboratory by the addition of an artificial lung to improve oxygenation and of a $1.2-\mu \mathrm{m}$ millipore filter (13). The flow rate of perfusion was maintained at $25-35 \mathrm{ml} / \mathrm{min}$ per kidney. The preparation was allowed to equilibrate for 15-20 min before the study period, which lasted $120 \mathrm{~min}$. Perfusion pressure and resistance were measured at 5-min intervals. Samples of the perfusate and urine were collected every $10 \mathrm{~min}$ for the determination of sodium, potassium, inulin and osmolality and the results were averaged every $30 \mathrm{~min}$. Sodium and potassium concentrations were determined by flame photometry (Flame Photometer Model 445) and inulin was determined according to Walson et al. (14). Fractional sodium tubular transport $\left(\% \mathrm{TNa}^{+}\right)$was calculated by the method of Pitts (15). The osmolality of the samples was measured with an Advanced Instrument osmometer (Needham Heights, MA, USA). After renal perfusion, the kidneys were evaluated histologically by light microscopy. The data are reported as mean \pm SEM for three periods of $10 \mathrm{~min}$ each at 30, 60, 90 and $120 \mathrm{~min}$. In each group, the first $30 \mathrm{~min}$ of perfusion were considered to be an internal control. The perfusion pressure (PP), urinary flow (UF), glomerular filtration rate (GFR) and $\% \mathrm{TNa}^{+}$remained stable in the control preparations throughout the 120-min perfusion. The data were analyzed by the Student $t$-test, with the level of significance set at $\mathrm{P}<0.05$.

Microcystins induce severe hepatic hemorrhage leading to shock (16). Gross macroscopic examination suggests that all the visceral organs are affected and the animal perhaps succumbs to multiple organ failure. However, except for the liver, gross histological examination of other visceral organs does not show any consistent abnormalities (17). Some conspicuous effects of microcystin-LR on carp kidney have been reported by Raberg et al. (18). These changes were apparently more severe than the relatively mild effects on kidney observed in mice (19-21). In addition, Kotak et al. (22) demonstrated kidney lesions in the fish (Oncorhynchus mykiss), consisting of coagulative tubular necrosis with dilation of Bowman's space. Bhattacharya et al. (23) showed a dose- and time-dependent elevation in plasma urea and creatinine levels with a concomitant decrease in total protein and albumin levels in rats. In view of these diverse observations, we have examined the potential nephrotoxicity of microcystin-LR in isolated perfused rat kidney, which permits the study of direct effects of toxin in the absence of systemic effects.

The infusion of $1 \mu \mathrm{g} / \mathrm{ml}$ microcystin-LR, which corresponds to $1 \mu \mathrm{M}$, after $30 \mathrm{~min}$ of an internal control caused a significant increase in perfusion pressure at $90 \mathrm{~min}$ (control $(\mathrm{C})=129.7 \pm 4.81$ and treated $(\mathrm{T})=$ $175.0 \pm 1.15 \mathrm{mmHg}, \mathrm{P}<0.05$ ). Urinary flow was also significantly increased with a maxi- 
mal effect at $90 \min (\mathrm{C}=0.20 \pm 0.01$ and $\mathrm{T}$ $\left.=0.32 \pm 0.01 \mathrm{ml} \mathrm{g}^{-1} \mathrm{~min}^{-1}, \mathrm{P}<0.05\right)$. GFR also increased at $90 \min (C=0.66 \pm 0.07$ and $\mathrm{T}=$ $\left.1.10 \pm 0.04 \mathrm{ml} \mathrm{g}^{-1} \mathrm{~min}^{-1}, \mathrm{P}<0.05\right) . \% \mathrm{TNa}^{+}$ was $78.6 \pm 0.98$ during the first $30 \mathrm{~min}$ of the internal control period and decreased significantly to $73.9 \pm 0.95(\mathrm{P}<0.05)$ at $120 \mathrm{~min}$ of perfusion after administration of the toxin (Table 1).

Histological evaluation of kidneys treated with microcystin-LR showed an intense amount of protein in the urinary spaces. The increase in perfusion pressure was followed by a significant increase in glomerular filtration rate. The time course of the effect of microcystin-LR on perfusion pressure coincided with that for glomerular filtration rate, suggesting that the latter effect is followed by an increase in perfusion pressure. This increase in perfusion pressure was probably responsible for the increase in glomerular pressure and, consequently, the increase in urinary flow. If microcystin-LR had a direct effect on the glomeruli we would expect a lesion resulting in an increase of glomerular filtration rate with a further increase in urinary flow rate. Sodium excretion depends on the relationship between glomerular filtration rate and sodium reabsorption rate. In the present experiments, the fractional sodium tubular transport was reduced in the microcystin-LR-treated group, this effect probably occurring in the proximal renal tubules. An important component of the glomerulus is the mesangium. Mesangial cells exhibit phagocytic activity and secrete prostaglandins and most of them also contain myofilaments and can contract in response to a
Table 1 - Effects of microcystin-LR on perfused rat kidney.

The kidneys were perfused with $1 \mu \mathrm{M}$ microcystin-LR (Mcyst) in modified KrebsHenseleit solution and control conditions. Data are reported as mean \pm SEM for 5 rats. *P $<0.05$ compared to control (Student t-test). PP, Perfusate pressure; GFR, glomerular filtration rate; UF, urinary flow; \% $\mathrm{TNa}^{+}$, fractional sodium tubular transport.

\begin{tabular}{lcccc}
\hline Time & $\begin{array}{c}\text { PP } \\
(\mathrm{mmHg})\end{array}$ & $\begin{array}{c}\text { GFR } \\
\left(\mathrm{m} \mathrm{g}^{-1} \mathrm{~min}^{-1}\right)\end{array}$ & $\begin{array}{c}\text { UF } \\
\left(\mathrm{ml} \mathrm{g}^{-1} \mathrm{~min}^{-1}\right)\end{array}$ & $\% \mathrm{TNa}^{+}$ \\
\hline 30 min & & & & \\
Control & $118.3 \pm 0.01$ & $0.73 \pm 0.06$ & $0.15 \pm 0.01$ & $81.3 \pm 0.16$ \\
Basal Mcyst & $129.7 \pm 4.81$ & $0.66 \pm 0.07$ & $0.20 \pm 0.01$ & $78.6 \pm 0.98$ \\
60 min & & & & \\
Control & $119.0 \pm 0.58$ & $0.72 \pm 0.03$ & $0.16 \pm 0.01$ & $82.0 \pm 0.46$ \\
M cyst & $160.7 \pm 8.69^{*}$ & $1.03 \pm 0.05^{*}$ & $0.28 \pm 0.02^{*}$ & $78.8 \pm 1.14$ \\
90 min & & & & \\
Control & $116.9 \pm 0.10$ & $0.74 \pm 0.05$ & $0.16 \pm 0.01$ & $81.0 \pm 0.44$ \\
M cyst & $175.0 \pm 1.15^{*}$ & $1.10 \pm 0.04^{*}$ & $0.32 \pm 0.01^{*}$ & $75.9 \pm 0.678^{*}$ \\
120 min & & & & \\
Control & $115.6 \pm 1.69$ & $0.74 \pm 0.05$ & $0.16 \pm 0.01$ & $80.6 \pm 0.32$ \\
M cyst & $175.3 \pm 1.45^{*}$ & $1.03 \pm 0.03^{*}$ & $0.31 \pm 0.02^{*}$ & $73.9 \pm 0.95^{*}$
\end{tabular}

variety of stimuli. Since mesangial cells are located in close contact with glomerular capillaries, they may influence the glomerular filtration rate by regulating blood flow through the capillaries (24). The intense amount of protein material was observed in the glomeruli of the toxin-treated group, probably because of toxic effects of the microcystin-LR on the glomeruli and tubules or due to an increase in vascular permeability due to endothelial injury. The present observations are the first demonstration of a direct specific effect of microcystin-LR, with alterations of renal functional parameters in the isolated perfused rat kidney in the absence of systemic effects. These renal effects are probably caused by inhibition of protein phosphatases.

\section{References}

1. Mackintosh C, Beattie KA, Klumpp S, Cohen P \& Codd GA (1990). Cyanobacterial microcystin-LR is a potent and specific inhibitor of protein phosphatases 1 and 2A from both mammals and higher plants. FEBS Letters, 264: 187-192.

2. Matsushima RN, Nishiwaki S, Ohta T,
Yoshizawa S, Suganuma M, Harada K-I, Watanabe MF \& Fujiki H (1991). Structure function relationships of microcystins, liver tumor promoters, in interaction with protein phosphatase. J apanese J ournal of Cancer Research, 82: 993-996.

3. Botes DP, Tuinman AA, Wessels PL,
Viljoen CC, Kruger $\mathrm{H}$, Williams $\mathrm{DH}$, Santikarn S, Smith RJ \& Hammond SJ (1984). The structure of cyanoginosin-LA, a cyclic heptapeptide toxin from the cyanobacterium Microcystis aeruginosa. J ournal of the Chemical Society Perkin Transactions, 1: 2311-2318. 
4. Rinehart $\mathrm{KL}$, Harada $\mathrm{Kl}$, Namikoshi $\mathrm{M}$, Chen C, Harvis CA, Munro MHG, Blunt J W, Mulligan PE, Beasley VR, Dahlem AM \& Carmichael WW (1988). Nodularin, microcystin, and the configuration of Adda. J ournal of the American Chemical Society, 110: 8557-8558.

5. Honkanen RE, Zwiller J , Moore RE, Daily SL, Khatra BS, Dukelow M \& Boynton AL (1990). Characterization of microcystinLR, a potent inhibitor of type 1 and type 2A protein phosphatases. J ournal of Biological Chemistry, 265: 19401-19404.

6. Ychihara A, Carmichael WW \& Fujiki $\mathrm{H}$ (1990). Inhibition of protein phosphatases by microcystin and nodularin associated with hepatotoxicity. J apanese J ournal of Cancer Research, 116: 609-614.

7. Claeyssens S, Francois A, Chedeville A \& Lavoinne A (1995). Microcystin-LR induced an inhibition of protein synthesis in isolated rat hepatocytes. Biochemical J ournal, 306 (Part 3): 693-696.

8. Ghosh $S$, Khan AS, Wickstrom $M$ \& Beasley V (1995). Effects of microcystinLR on action and the actin-associated proteins alpha-actinin and talin in hepatocytes. Natural Toxins, 3: 405-414.

9. Bahlmann J, Giebisch $\mathrm{G} \&$ Ochwadt B (1967). Micropuncture study of isolated perfused rat kidney. American J oumal of Physiology, 212: 77-82.

10. Nishiitsutji-Uwo GM, Ross BD \& Krebs HA (1967). Metabolic activities of the isolated perfused rat kidney. Biochemical J ournal, 103: 852-862.
11. Ross BD (1978). The isolated perfused rat kidney. Clinical Science and Molecular Medicine, 55: 13-21.

12. Bowman RH (1970). Gluconeogenesis in the isolated perfused rat kidney. J ournal of Biological Chemistry, 245: 1604-1612.

13. Fonteles MC, Cohen JJ, Black AJ \& Wertheim SJ (1983). Support of renal kidney function by long-chain fatty acids derived from renal tissue. American J ournal of Physiology, 244: 235-246.

14. Walson M, Davidson DG \& Orloff J (1955). The renal clearance of alkali-stable inulin. J ournal of Clinical Investigation, 34: 15201523.

15. Pitts RK (1971). Metabolism of amino acids by the perfused rat kidney. American J ournal of Physiology, 220: 862-867.

16. Runnegar MTC \& Falconer IR (1982). The in vivo and in vitro biological effects of the peptide hepatotoxin from blue-green alga Microcystis aeruginosa. South African J ournal of Science, 75: 363-366.

17. Theiss WC \& Carmichael WW (1986). Physiological effect of a peptide toxin produced by fresh-water cyanobacteria (bluegreen algae) Microcystis aeruginosa strain 7820. In: Steyn PS \& Vleggaar R (Editors), Mycotoxin and Phycotoxin, Bioactive Molecules. VI. Elsevier, Amsterdam, 353-364.

18. Raberg CMI, Bylund $\mathrm{G} \&$ Eriksson JE (1991). Histopathological effects of microcystin-LR, a cyclic peptide toxin from cyanobacterium (blue-green alga) Microcystis aeruginosa, on common carp (Cyprinus carpis L.). Aquatic Toxicology,
20: 131-146.

19. Eriksson J E, Meriluoto J AO, Kujari HP \& Skulberg OM (1988). A comparison of toxins isolated from the cyanobacteria Oscillatoria agardhii and Microcystis aeruginosa. Comparative Biochemistry and Physiology, 89C: 207-210.

20. Meriluoto J AO, Sandstroms A, Eriksson J E, Remaud G, Craig AG \& Chattopadhyaya J (1989). Structure and toxicity of a peptide hepatotoxin from the cyanobacterium Oscillatoria agardgii. Toxicon, 27: 1021-1034.

21. Hooser SB, Beasley VR, Lovell RA, Carmichael WW \& Haschek WM (1989). Toxicity of microcystin-LR, a cyclic heptapeptide hepatotoxin from Microcystis aeruginosa to rat and mice. Veterinary $\mathrm{Pa}$ thology, 26: 246-252.

22. Kotak BG, Semalulu S, Fritz DL, Prepas EE, Hrudey SE \& Coppock RW (1996). Hepatic and renal pathology of intraperitoneally administered microcystin-LR in rainbow trout (Oncorhynchus mykiss). Toxicon, 34: 517-525.

23. Bhattacharya R, Sugendran K, Dangi RS \& Lakshmana Rao PV (1997). Toxicity evaluation of freshwater cyanobacterium $\mathrm{Mi}$ crocystis aeruginosa PCC 7806. II. Nephrotoxicity in rats. Biomedical and Environmental Sciences, 10: 93-101.

24. Koeppen BM \& Stanton BA (1992). Structure and function of the kidneys and the lower urinary tract. In: Kist K (Editor), Renal Physiology. Mosby Year Book, St. Louis, MO, 22-23. 